\title{
McArdle's disease with late-onset symptoms: case report and review of the literature
}

\author{
Kevin J Felice, Andrea B Schneebaum, H Royden Jones Jr
}

\begin{abstract}
McArdle's disease with late-onset symptoms is an unusual cause for muscle disease in older patients. The case of a patient with McArdle's disease whose symptoms began at 60 years of age is presented, and seven previous cases of late-onset McArdle's disease reported since 1963 are discussed. In five of the eight patients, the clinical presentation was similar to the early onset disorder with exercise intolerance, cramps, and myoglobinuria. In contrast, the remaining three patients presented with fixed proximal limb and bulbar weakness. Electromyography confirmed a myopathic process in four of four patients. Results of the forearm ischaemic exercise test were positive in seven of seven patients with complete myophosphorylase deficiency; results of muscle biopsies were diagnostic in all patients. McArdle's disease with late-onset symptoms is rare and clinically more variable than the early onset disorder.
\end{abstract}

McArdle's disease is an energy-dependent disorder of skeletal muscle caused by a deficiency of myophosphorylase, an important enzyme of carbohydrate metabolism that converts glycogen to glucose-1-phosphate. ${ }^{1}$ Because the energy produced by glycolysis is reduced in patients with a deficiency of myophosphorylase, symptoms of exercise intolerance, muscle cramps, and weakness usually predominate during short bursts of highintensity exercise. Many patients experience a second wind, that is, when they rest briefly after cramps first appear, they can resume exercise without further symptoms. McArdle ${ }^{2}$ first described the disorder in 1951 in a 30 year old man with lifelong intolerance to exercise.

Typically, patients note exercise intolerance with muscle cramps during teenage years; rarely do symptoms begin after the age of 30 years. ${ }^{3}$ In 1963 , Engel et $a l^{4}$ reported the first two cases of late-onset deficiency of myophosphorylase. We describe an additional case and review the clinical, laboratory, and pathological data on previously reported cases. ${ }^{4-9}$

\section{Case report}

A 70 year old man was referred for severe exercise-induced cramps in the upper extrem- ities associated with an elevated serum creatine kinase (CK) level.

The patient first experienced mild cramping in the upper extremities during exercise when he was 60 years old despite having lived a vigorous life playing football as a teenager and working on a loading dock as an adult. He gave no history of ever passing dark-coloured urine nor a family history of muscle disease, cramps, or weakness. Several months before our evaluation, he experienced severe painful cramps in the hands and forearms when he tensely gripped the steering wheel during a long distance drive. The emergency room evaluation two days later revealed isolated elevation of the serum CK level to $8,750 \mathrm{U} / \mathrm{L}$ (normal, 30 to $194 \mathrm{U} / \mathrm{L}$ ), and a positive antinuclear antibody staining (ANA). Electromyography showed a patchy myopathic process, and oral administration of prednisone was started. Soon afterward the pain resolved, and the serum CK level became normal. Two weeks before our examination, focal cramps in the right arm returned while the patient was hammering nails. The serum $C K$ level increased to $411 \mathrm{U} / \mathrm{L}$ and again returned to normal $(126 \mathrm{U} / \mathrm{L})$ by the time of our evaluation.

Results of general and neurological examination were normal, with no evidence of weakness, atrophy, fasciculations, cramps, or myotonia. Results of forearm ischaemic exercise test revealed no rise in serum lactate levels after exercise despite a sharp rise in ammonia consistent with a defect in glycolysis. Muscle biopsy revealed scattered fibres with small subsarcolemmal collections of PAS-positive material and complete absence of myophosphorylase activity.

\section{Discussion}

This patient's symptoms of McArdle's disease began in the seventh decade. An inflammatory myopathy was originally suspected because of elevated serum levels of $\mathrm{CK}$, the results of electromyography, the positive ANA staining, and the suggested alleviation of symptoms with oral prednisone therapy. However, the history of repeated bouts of exercise-induced cramps suggested a metabolic myopathy. Positive results on forearm ischaemic exercise test and muscle biopsy confirmed the diagnosis of McArdle's disease.

Seven other cases of McArdle's disease with late-onset symptoms (that is, at the age of 45 
Table Late-onset myophosphorylase deficiency: clinical and laboratory features

\begin{tabular}{|c|c|c|c|c|c|c|c|c|c|}
\hline \multirow[b]{2}{*}{ Author } & \multirow[b]{2}{*}{ Case } & \multirow[b]{2}{*}{ Sex } & \multicolumn{2}{|c|}{ Age (Year) } & \multirow{2}{*}{$\begin{array}{l}\text { Family } \\
\text { History }\end{array}$} & \multirow{2}{*}{$\begin{array}{l}\text { Clinical } \\
\text { Symptoms }\end{array}$} & \multirow{2}{*}{$\begin{array}{l}\text { Serum Creatine } \\
\text { Kinase Levels }\end{array}$} & \multirow{2}{*}{$\begin{array}{l}\text { Forearm Ischaemic } \\
\text { Exercise Test }\end{array}$} & \multirow{2}{*}{ Electromyography } \\
\hline & & & Onset & Present & & & & & \\
\hline $\begin{array}{l}\text { Engel } e t a l^{4} \\
\text { Hewlett et } a l^{5} \\
\text { Kost et } a l^{6} \\
\text { Rumpf } e t a l^{7} \\
\text { Meinck et } a l^{8} \\
\text { Pourmand } e t a l^{9} \\
\text { Present case }\end{array}$ & $\begin{array}{l}1 \\
2 \\
3 \\
4 \\
5 \\
6 \\
6 \\
7 \\
8\end{array}$ & $\begin{array}{l}\mathbf{F} \\
\mathbf{M} \\
\mathbf{M} \\
\mathbf{F} \\
\mathbf{M} \\
\mathbf{M} \\
\mathbf{M} \\
\mathbf{M}\end{array}$ & $\begin{array}{l}49 \\
49 \\
74 \\
60 \\
53 \\
53 \\
73 \\
60\end{array}$ & $\begin{array}{l}52 \\
60 \\
74 \\
60 \\
57 \\
57 \\
75 \\
70\end{array}$ & $\begin{array}{l}\text { Yes } \\
\text { Yes } \\
\text { No } \\
\text { No } \\
\text { No } \\
\text { No } \\
\text { No } \\
\text { No }\end{array}$ & $\begin{array}{l}\text { PW, EI } \\
\text { C, EI } \\
\text { PW, FW, P } \\
\text { C, EI, M } \\
\text { PW, EI, SW, C } \\
\text { PW, C, EI, SW, M } \\
\text { PW, D } \\
\text { EI, C }\end{array}$ & $\begin{array}{l}\text { Normal } \\
\text { Normal } \\
\text { Elevated } 13 \times \\
\text { Elevated } 210 \times \\
\text { Elevated } 3-12 \times \\
\text { Elevated } 8 \times \\
\text { Minimal } 1.3 \times \\
\text { Elevated } 2-40 \times\end{array}$ & $\begin{array}{l}\text { Positive } \\
\text { Normal } \\
\text { Positive } \\
\text { Positive } \\
\text { Positive } \\
\text { Positive } \\
\text { Positive } \\
\text { Positive }\end{array}$ & $\begin{array}{l}\text { Not available } \\
\text { Not available } \\
\text { MU } \\
\text { Not available } \\
\text { Not available } \\
\text { MU, AS } \\
\text { MU, AS } \\
\text { MU, AS }\end{array}$ \\
\hline
\end{tabular}

$\mathrm{PW}=$ progressive weakness, $\mathrm{EI}=$ exercise intolerance, $\mathrm{C}=$ cramps, $\mathrm{FW}=$ facial weakness, $\mathrm{P}=$ ptosis, $\mathrm{M}=$ myoglobinuria, $\mathrm{SW}=$ second wind,

$\mathrm{D}=$ dysphagia, $\mathrm{MU}=$ myopathic units, $\mathrm{AS}=$ abnormal spontaneous activity.

years or older) described in the English literature since the 1963 report of Engel et al are correlated with our patient (table). Of the eight patients, five had exercise-induced cramps, including two patients with myoglobinuria. In contrast, three patients (cases 1, 3, and 7) presented with fixed proximal weakness without a history of muscle cramps. Although fixed weakness occurs in typical McArdle's disease, this weakness usually develops in the later stages of the disease after repeated bouts of exercise-induced symptoms. ${ }^{3}$ In addition, bulbar weakness, including ptosis, facial weakness, and dysphagia, developed in two of the three patients without cramps. In the large series of DiMauro and Bresolin, ${ }^{3}$ no weakness in the cranial musculature was reported. A metabolic myopathy may not have been diagnosed in these three atypical patients with fixed proximal weakness and bulbar symptoms had it not been for the rigorous laboratory evaluations.

Electromyography was reported in four of the eight patients and demonstrated myopathic units in each. In three of these patients, abnormal spontaneous activity (that is, fibrillations, positive waves or complex repetitive discharges) in proximal muscles suggested the possibility of an inflammatory myopathic process. This feature has been noted rarely in the early onset disorder. ${ }^{310}$

Forearm ischaemic exercise tests were positive in seven of eight patients. Each had complete histochemical absence of myophosphorylase at muscle biopsy despite only minimal glycogen storage and myopathic features. The only exception was the one patient with partial deficiency of myophosphorylase (case 2) in whom results of forearm ischaemic exercise tests demonstrated a normal rise in serum lactate level after exercise.

McArdle's disease with late-onset symptoms is a rare disorder with more variable clinical presentation than the early onset disorder. Myophosphorylase deficiency should be considered in older patients with unexplained generalised or focal myopathies with or without muscle cramps and including patients with bulbar features. A positive result on forearm ischaemic exercise testing is a sensitive initial study which, when results are positive, should lead to histochemical evaluation on muscle biopsy.

We thank Dr A Engel, Mayo Clinic Neuromuscular Laboratory, for interpretation of the muscle biopsy specimen in this patient and $\mathrm{Dr} \mathrm{N}$ Lee for her critical analysis and suggestions on the manuscript.

1 Cornelio F, Di Donato S. Myopathies due to enzyme deficiencies. F Neurol 1985;232:329-40.

2 McArdle B. Myopathy due to defect in muscle glycogen breakdown. Clin Sci 1951;10:13-35.

3 DiMauro S, Bresolin N. Phosphorylase deficiency. In: Engel AG, Banker BQ, eds. Myology New York: McGraw Hill, 1986;1585-601.

4 Engel WK, Eyerman EL, Williams HE. Late-onset type of skeletal-muscle phosphorylase deficiency. A new familial variety with completely and partially affected subjects. $N$ Engl f Med 1963;268:135-7.

Hewlett RH, Gardner-Thorpe C. McArdle's disease-what limit to the age of onset? $S$ Afr $\mathcal{F}$ Med 1978;53:60-3.

6 Kost GJ, Verity MA. A new variant of late-onset myophosphorylase deficiency. Muscle Nerve 1980;3:195-201.

7 Rumpf KW, Wagner H, Kaiser H, Meinick HM, Goebel HH, Scheler F. Increased ammonia production during HH, Scheler F. Increased am in McArdle's disease. Wochenschr 1981;59:1319-20.

8 Meinck HM, Goebel HH, Rumpf KW, Kaiser H, Neumann P. The forearm ischaemic work test-hazardous to P. The forearm ischaemic work test-hazardous to
McArdle patients? $\boldsymbol{f}$ Neurol Neurosurg Psychiatry McArdle patients?

9 Pourmand R, Sanders DB, Corwin HM. Late-onset McArdle's disease with unusual electromyographic findings. Arch Neurol 1983;40:374-7.

10 Higgs JB, Blaivais M, Albers JW. McArdle's disease presenting as treatment resistant polymyositis. I Rheumatol 1989;16:1588-91. 